\title{
Analysis of the trend of ideological and political education of college students under the internet background
}

\author{
Huanhuan Lei \\ Chongqing College of Electronic Engineering, Chongqing, 401331, China
}

\begin{abstract}
Keywords: Internet, background, college students, ideological and political education, trend, analysis.
\end{abstract}

\begin{abstract}
The rapid popularization of Internet has an increasingly profound impact on the ideological and political education of college students. This paper analyzes the opportunities and challenges facing the ideological and political education of college students under the background of Internet, discusses the basic concept of network ideological and political education work from the practical innovation angle, finally from the aspects of team construction, build a platform, public opinion survey, and service activities to promote the research put forward a path of network ideological and political education. Under the background of the Internet era, how to strengthen the political education of Marx thought and innovate the content of Ideological and political education of college students is not only the historical mission entrusted by the times. At the same time, it is also for the maintenance of social stability, improve the ideological consciousness of college students and establish a correct outlook on the world. This paper analyzes, explores and studies the content of ideological and political education of college students under the Internet background.
\end{abstract}

\section{Introduction}

With the rapid development and popularization of the Internet, the Internet has become an important social, trading and other public platform for people's work and life. Although the network developed to people in the life and work to bring information consultation and resource sharing is convenient, but the contradictions bring about people's thinking and ideological impact, challenges and conflicts are unavoidable at present. Under the background of the Internet era, how to strengthen the political education of Marx thought is not only the historical mission entrusted by the times. At the same time, in order to maintain social stability, and to meet the needs of people to improve their ideological awareness and establish a correct outlook on the world. Nowadays, the practice of Ideological and political education in our departments still follows the traditional book education, slogan raising and oral encouragement. This is now out of the Internet era is clearly out of line. How to innovate, improve and expand the content of Ideological and political education of college students under the internet background is an important task for educators and government departments at all levels.

The Internet provides college students with the latest and most abundant information to make their minds more active. But the network information is complicated, some superstition, pornography, violence is not conducive to social stability the widespread dissemination of information, also continue to affect the thinking of students, and even the impact of their world outlook, outlook on life and values. The mode of ideological and political education needs to be improved. A variety of spaces, forums, blogs, micro-blog, social networking sites and other trendy platforms are attractive to college students, who are more willing to communicate and solve problems across the network. The equality of network communication makes educators and educated people more equal, and the traditional ideological and political education model can not meet the needs of the work. The complexity of the effect evaluation of college students' ideological and political education. The network is a huge temptation, with persistent, recurrent, once the students are addicted to the Internet, it takes a long time and repeated education can be successful treatment. This also makes repeated assessment of Ideological and political education effect is more complex. 
The Internet action plan first proposed by Premier Li Keqiang in the government work report, the Internet represents a new form, that is to make full use of the Internet in the optimal allocation of production factors in the role of innovation and integration, the depth of the integration of the Internet in all areas of the economy and society of. As an important carrier of serving the society and imparting knowledge and educating people, colleges and universities are also the most active platform for Internet applications. It can effectively promote the popularization of Internet education. The Internet education mode refers to the integration of the traditional teaching model with the new media to make up for the shortcomings of traditional teaching and open up a new field of education. The Internet ideological and political education is to the Internet as the carrier of education, encourage students to form a certain social norms and moral values of the social practice of college students, is the new way of Ideological and political guidance under the new situation.

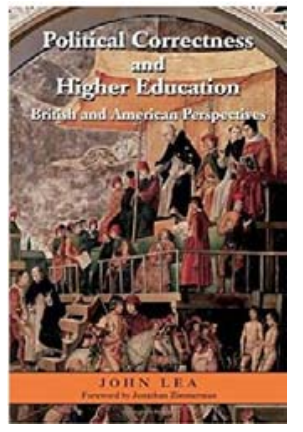

Figure 1. Ideological and political education

\section{The Proposed Methodology}

\subsection{Ideological and Political Education of College Students under the Background of Internet.}

With the development of education and teaching reform in our country, the demand for higher education in our country is also rising. So far, the number of colleges and universities in our country has accounted for more than 1000. In the development of these colleges and universities, educators are actively responsive to the call of the government, and attach great importance to the ideological and political education of college students. The state also opened a lot of norms to strengthen ideological and political education of college students, the requirements in the network environment, the network ideological and political education occupies the rights, and the formation of the ideological and political education work system. In the current higher education, the course of Ideological and political education has been basically established. With the continuous popularization of the Internet, ideological and political education is expanding with the mode of Internet education.

People's ideas have changed with the development of society and economy. With the development of Internet, people's ideas and ideas have changed greatly. Under the background of the current Internet environment, the ideological and political education of college students is systematically analyzed and interpreted.

\subsection{Educational Methods and Educational Channels.}

China's ideological and political education mode of education is in accordance with the book knowledge to the work of education and teaching, the traditional class communication channel is focused on television, radio and related books and the ideological and political education. It is obvious that this traditional mode of education and means of communication have become disconnected from the society under the current Internet environment. Moreover, the traditional propaganda pays too much attention to the analysis of the framework of Marx's theory and knows very little about how to combine the content system with modern society.

To change this situation, the first thing to do is to strengthen the intensity of Internet publicity, and gradually change the mode of publicity, the mode of change in the form depends on the implementation of specific ideological and political education.

\subsection{Ideological and Political Education Strategy.}

The strategy of ideological and political education mainly refers to the promotion of the competitiveness of educational platform in the current Internet environment. Today's ideological and 
political education competition, and its way of thinking will directly affect the students' psychological trend, training students is actually a follow-up to the country's strength. It is also the duty and obligation of the state to train the next generation. Therefore, the cultivation of college students' ideological and political education has become an important part of our current education and teaching work. In the Internet era, many friendly countries after seeing the vigorous development of our country, the development of a series of measures taken to suppress all areas of our country, even make a lot of damage the social stability of China news. In the face of these information, if there is no real guiding college students ideological and political education to establish a correct view, so students are easily influenced by the information, and then through the Internet to transfer these information, it is likely to mislead students, resulting in their own ideological and political ideas shift, will produce unstable factors much of China's social development.

\subsection{The Basic Idea of Ideological and Political Education.}

To carry out the ideological and political education of college students, we should establish an open concept of education. Make full use of the Internet and attract college students in vivid form. The Internet is just a tool. The key is how to use it. The work of ideological and political education after all must carry out the human body, the starting point of the network ideological and political education and goal must be under the net, the net work is the foundation of the Internet are expanding, net work and work to combine online. The workers of ideological and political education should be in-depth study of network ideological and political education law, strengthening the connotation construction of network ideological and political education, increase the network ideological and political education and cultural characteristics, to carry out innovative education activities according to the characteristics of the Internet, firmly attracted college students.

One of the characteristics of ideological and political education is penetration. Therefore, we should consider and plan systematically, and guide, educate, carry out and infiltrate into the work of college students. Educators should adhere to the students as the center, continue to study the characteristics of thought and behavior of college students, often listen to their voices, to accurately grasp the structure characteristics of college students, analyze their ideological confusion and demand, adopt different guidance method, for different groups of discourse system, and strive to create a healthy campus cultural atmosphere and the atmosphere of public opinion to the network the efforts to improve the ideological and political education of the pertinence, effectiveness and affinity, appeal.

\subsection{Ideological and Political Education Work.}

Train talents, strengthen the construction of ideological and political education team. First of all, strengthen the ideological and political education full-time team construction, to build a political, network technology, and familiar with the campus network culture work team. Secondly, training a group of backbone students, responsible for the network ideological and political education by their specific operation and routine maintenance, they are not only the teacher's assistant, is the ideological and political education of information and publicity. Finally, the school provides the necessary conditions, regularly carry out training and guidance to the team, strengthen work supervision and assessment.

To carry out services and research, and constantly improve the level of scientific work. Ideological and political education should be concerned about what the students care about, provide the services that students need, and help students grow up and become useful. Especially for development, concern at the quality of the students scientific and technological innovation, mental health, advocacy services, Graduate employment and entrepreneurship abroad, and so on, the department of students work and workers should take positive action, research student demand, contact social resources, use the network to provide information and services for the majority of students. All services should be centered on the needs of students, and serve to guide students in their pursuit of progress and help them grow and become useful. At the same time, we should also be good at summing up experience and lessons, strengthen thinking and research, and work hard to solve the difficult problems in our work.

At present, the ideological education of college students mainly focuses on book education. The channels of communication in the classroom are also reflected in radio, television, newspapers and 
some related books. Traditional education and traditional ways of communication have been out of touch with the times. And in the propaganda content, pays attention to is to the Marx doctrine theory frame composition and the theory system elaboration. The Marx thought how to combine with the modern practical ideology and rarely, in theory propaganda, some theory of language is too abstruse, make it difficult to understand. Therefore, such a problem has become a major problem puzzling the ideological education of college students. And in the intensity and way of Internet publicity, we should expand the mode of publicity and increase publicity efforts.

\subsection{The Development of Ideological and Political Education.}

Internet is not only the carrier of information communication, but also the platform of information exchange. In the network flow model, a lot of information coming, dizzying. The primary task of our current ideological and political education is to make Marx's ideological and political education system has become a major force in the numerous information, let Marx thought education become college students love to read, want to read and read the information, thus changing the students to just study for the exam mode. Let the students ideological and political education change from passive to active, this change is not a short duration of time can be completed, the first thing to do is to lay a good foundation for ideological and political education content, which requires our experts, scholars and educators together to make the ideological and political education in the current practice, make the ideological and political education the content can be guide to contemporary college students life. Change political, ideological and educational content unchanged model for many years, make political and ideological education become practical. The only way to Internet information in many talent shows itself, become college students love to read, want to read and read the contents of the Internet, allowing the students to establish the correct values and world outlook in the subtle, to allow the Internet becoming the main position of ideological and political education of college students.

\section{Conclusion}

The content of the ideological and political education innovation under the background of Internet is established during the actual development of the current social system of the requirements in the way of education and education channels increased, and the college students' ideological and political education strategy change, and constantly improve the relevant measures of Ideological and political education of college students, checks the content on the Internet fundamentally. In the content of propaganda, ideological and political education workers not confined to the theoretical framework of Marx, to the ideological and political education and the reality of life together, and teach in the theoretical knowledge of the ideological and political education, ideological and political teachers should use simple and direct language to expand students' understanding and cognition of the ideological and political education and promote the formation of college students' ideological and political value concept.

\section{References}

[1]. Wang D. Construct of the Content System of Ideological and Political Education in Human Concern [J]. Teaching \& Research, 2005.

[2]. Cui Y C. "Student-oriented" Education: the Core of Ideological and Political Education in University in a New Age [J]. Journal of Hebei University of Economics \& Trade, 2007, 38(5):1267-1273.

[3]. Ming L I. Experiential Education: Useful Trails in Enhancing Effectiveness of the Ideological and Political Education of College Students [J]. Higher Education Forum, 2008, 11(4):739-752.

[4]. Shang S S. On ideological and political education for college students in inter net situation [J]. Journal of Hubei Normal University, 2004. 